\title{
The Effect of Complete Prosthesis Treatment on Serum Iron and Folic Acid Levels in Prosthetic Patients of Tehran Dental School
}

\author{
Zahra Nouri ${ }^{1}$ (i), Nima Norouzi ${ }^{2, *}$ (i) \\ 1 School of Medicine, Tehran University of Medical Sciences, Tehran, Iran; zn65133@ gmail.com (Z.N.); \\ 2 School of Energy and Physics, Amirkabir university of technology (Tehran Polytechnic); nima1376@ aut.ac.ir (N.N.); \\ * Correspondence: nima1376@aut.ac.ir;
}

\begin{abstract}
Nutrition of toothless patients and providing their diet in a way that can meet the nutritional needs of their body should always be considered in providing a complete prosthesis. Tehran Dental School, before and after receiving alternative prostheses and examining changes in their serum levels. In this interventional study, the subjects were 30 patients referred to the prosthetics department, including 17 women and 13 men. The data collection tool was a standardized questionnaire consisting of two parts, the first part containing personal information. The second part included a table in which information about the primary and secondary levels of iron and folic acid in the serum was identified. The primary level of iron and folic acid after 3 months of the edentulous period and the secondary level indicated the serum level of the two, three months after the delivery of the complete prosthesis (artificial teeth). Then, paired t-test and independent t-test were used for statistical analysis. Evaluation of the data obtained from the study population, whose mean age was 52.6 years, showed a low serum level of iron and folic acid in these people compared to normal people, both in primary and secondary sampling. Also, changes in the secondary level of iron compared to the primary level did not show a significant decrease, while this decrease was significant for folic acid $(\mathrm{P}=0.003)$. The study of these changes in terms of sex difference also showed only a significant difference in serum iron $(P=0.012)$, while in the case of folic acid, there was no difference in the rate of secondary reduction between men. The placement of alternative prostheses in toothless people could not affect improving their diet. For this reason, these patients should be trained to modify their diet with supplements and other substances when delivering prostheses or to have control courses in terms of health and nutrition.
\end{abstract}

Keywords: complete denture; serum levels of iron; folic acid; prosthetic patients; complete prosthesis.

(C) 2020 by the authors. This article is an open-access article distributed under the terms and conditions of the Creative Commons Attribution (CC BY) license (https://creativecommons.org/licenses/by/4.0/).

\section{Introduction}

Nutrition of toothless patients and guiding their diet to meet their body's nutritional needs should always be considered in making and providing prostheses. Spending a period of edentulousness between the extraction of teeth to their replacement with dentures and then the condition of dentures in terms of chewing power, in addition to the patient's eating habits, is effective in restoring the dentition to good health. Today, the role of minerals and vitamins in metabolic and health reactions has become clear to everyone. Iron and folic acid are known to be important elements in the body's metabolism. The amount needed by the body for different 
ages has been determined. Many factors affect the blood levels of iron and folic acid in the body. Proper nutrition and chewing power have an undeniable role [1].

Most of the iron in the body is in the blood, but some are in all cells. There is considerable evidence that iron is important in many of the functions associated with blood formation and oxygen transport. The functions of non-heme iron are to synthesize nucleic acid, remove blood lipids, synthesize collagen, produce antibodies, and detoxify drugs in the liver $[2,3]$. The body needs iron, the type of iron (ferric or ferrous), the composition of the food, the volume of the diet, the amount of food, and other factors such as celiac disease that leads to fatty stools, low altitude, the presence of phytic acid or phosphorus or even Theine in tea and coffee (they have the opposite effect on iron absorption) are involved in iron absorption [1].

The normal level of serum iron is 50 to 150 micrograms per deciliter. Transferrin saturation, typically $25-50 \%$, and iron deficiency are associated with less than $18 \%$ saturation [2]. The serum ferritin level is the best laboratory indicator for estimating iron stores (3).

Normal levels of ferritin vary depending on the age and sex of the individual. Male adults have a serum ferritin level of about $100 \mu \mathrm{g} / \mathrm{dl}$, while females have about $30 \mathrm{~g} / \mathrm{dl}$. By depleting iron stores, serum ferritin levels drop to 15 micrograms per deciliter. Such values usually indicate a lack of iron stores in the body [3].

Folic acid is indirectly involved in synthesizing enzymes and the synthesis of other protein compounds [4]. The amount of folic acid recommended by the FAO/WHO for adolescents and adults is $0.4 \mathrm{mg}$ or 400 micrograms per day. This value is considered with a probability of 25 to $50 \%$ absorption [3]. Alternative therapies correct folate deficiency. The usual folate dose is $1 \mathrm{mg}$ /day orally. However, higher doses of up to $5 \mathrm{mg} /$ day are required for malabsorption deficiencies. Also, Injectable folate is rarely needed [1, 4].

A study of American citizens by Nowjack-R found that the absorption of nutrients, fiber, and biochemical components in toothless individuals (taking into account dietary habits and cultural and social factors) To people with lower teeth. This study states that the intake and intake of foods rich in $\beta$-carotene, folate, and vitamin $\mathrm{C}$ in people with dentures are lower than in people with natural teeth [5].

Marshall et al. Conducted a study in 2002 to examine the relationship between dietary diversity, nutrient uptake, and dental health. The results showed that superior nutrition in these men is associated with more and better dietary diversity [6]. Ettinger RL, with its study in 1998, showed that there is a strong association between changes in dental status such as tooth loss and the quality of dentures with low food intake [7-9]. Shinkai RS and colleagues in 2002 showed that the quality of dentures, food absorption capacity, and the ability to chew are not related to the quality of the diet. A large group of the study population had incomplete diets despite the poor quality of dentures. This study showed that dentures' presence reduces the diet's absorption and poverty, and its quality has no effect on the diet [8]. In a 1995 study of 86 women between the ages of 54 and 74 who came to the dental clinic, Sheffers et al. complete dentures were lower than the others, which disappeared after diet modification [9-14]. Brodeur JM showed that in people with poor chewing function, lack of absorption of fruits and vegetables in both sexes, and decreased absorption of vitamin A in women. Also, people with poor chewing function received more medication than people with useful chewing function. Therefore, reducing fiber-rich foods' consumption can increase toothless older adults [14-20]. This study aimed to measure the serum levels of iron and folic acid among several patients referred to the prosthetics department of Tehran Dental School before and after receiving a complete prosthesis and comparing them. 


\section{Materials and Methods}

This interventional study was performed on 30 clients of the prosthetics department of Tehran Dental School with a mean age of 52.6 years, which included 17 women and 13 men over 45 years. The subjects were selected from clients who were not generally healthy and had diseases affecting folic acid. These people used their teeth for the first time. A questionnaire was used on a sheet containing personal and medical information of the client and a table designed to record laboratory amounts of iron and folic acid to collect the data. After selecting the patients, blood samples were taken twice from each patient. The first sample was taken on the day of prosthesis delivery. The second sample was performed three months after prosthesis delivery. It should be noted that all subjects underwent approximately the same period in terms of duration of edentulousness, which averaged 3 months. Ferene-S method and its special kit were used to measure iron and folic acid in blood samples. Normal serum iron levels are routinely 40-155 micrograms per deciliter in women and 60-180 micrograms per deciliter in men. The folic acid detection test was based on the use of RIA (Radio Immuno assay) method with 57 cobalt. In this study, descriptive statistical methods were used to classify and calculate statistical indicators. Independent t-test and paired t-test were used to compare the means [2030].

\section{Results and Discussion}

After collecting the questionnaires and extracting the data, the information in the tables was analyzed. The following results were obtained. The mean serum iron level in the prototypes (at the time of prosthesis delivery) was $92.283 \mu \mathrm{g} / \mathrm{dl}$. The changes' amplitude was 63, with the lowest serum iron level being $56 \mu \mathrm{g} / \mathrm{dl}$ and the highest serum iron level being 119 $\mu \mathrm{g} / \mathrm{dl}$.

\subsection{Mean primary and secondary levels of iron and folic acid in the study population.}

The mean serum level of folic acid in the prototypes (at the time of prosthesis delivery) was $5.343 \mathrm{ng} / \mathrm{ml}$ with a standard deviation of 4.70 and a range of changes of 3.20 , with the lowest serum folic acid level being $3.20 \mathrm{ng} / \mathrm{ml}$ and the highest $\mathrm{ng} / \mathrm{ml}$ was 7.90 as shown in Table 1.

Table 1. Comparison of mean primary and secondary serum levels of iron and folic acid in the study population with normal values.

\begin{tabular}{l|c|c|c|c|c}
\multirow{2}{*}{} & \multicolumn{2}{|c|}{ Primary } & \multicolumn{2}{c|}{ Secondary } & \multirow{2}{*}{ t-test Results } \\
\cline { 2 - 5 } & Mean & Std. Dev. & Mean & Std. Dev. & \\
\hline Ferrum $(\boldsymbol{\mu g} / \mathbf{d l})$ & 92.283 & 17.800 & 85.160 & 19.430 & $\mathrm{P}=0.1000$ \\
\hline Folic Acid $(\mathbf{n g} / \mathbf{m l})$ & 5.3430 & 4.7000 & 4.6530 & 1.3270 & $\mathrm{P}=0.0030$
\end{tabular}

The mean serum iron level in the second samples (three months after prosthesis delivery) was 85.160 micrograms per deciliter. The range of changes was 100 . The lowest serum iron level was $42 \mu \mathrm{g} / \mathrm{dl}$, and the highest was $142 \mu \mathrm{g} / \mathrm{dl}$. The mean serum level of folic acid in the second samples (three months after prosthesis delivery) was $4.653 \mathrm{ng} / \mathrm{ml}$. The range of changes was 5.90, with the lowest serum folic acid level being $2.20 \mathrm{ng} / \mathrm{ml}$ and the highest $10.80 \mathrm{ng} / \mathrm{ml}$, which was mentioned in the table. In this part, no significant difference was observed in the amount of primary and secondary iron. However, the study of primary and secondary folic acid levels showed a significant decrease in serum folic acid levels during the study period $(\mathrm{P}=0.003)$. 
3.2. Comparison of primary and secondary levels of iron and folic acid in the study population by sex.

The mean and standard deviation of primary and secondary levels for females and iron for iron and folic acid are shown in Table 2. Comparison of primary $(\mathrm{P}=0.019)$ and secondary $(\mathrm{P}=0.012)$ serum levels of iron in the two sexes show a significant difference. However, the comparison of primary and secondary serum levels of folic acid did not differ between the two sexes. Figures 1 and 2 are related to comparing primary and secondary serum levels of iron and folic acid by sex.

Table 2. Comparison of the mean and standard deviation of primary and secondary levels of iron and folic acid

\begin{tabular}{l|l|c|c|c|c}
\multirow{2}{*}{} & \multicolumn{2}{c}{ Female } & \multicolumn{2}{c}{ Male } & \multirow{2}{*}{ t-test Results } \\
\cline { 2 - 5 } & Mean & Std. Dev. & Mean & Std. Dev. & \\
\hline Ferrum $(\boldsymbol{\mu g} / \mathbf{d l})$ & 85.140 & 12.180 & 100.00 & 15.460 & $\mathrm{P}=0.0190$ \\
\hline & 77.240 & 13.430 & 93.180 & 21.180 & $\mathrm{P}=0.0120$ \\
\hline Folic Acid $(\mathbf{n g} / \mathbf{m l})$ & 6.0400 & 1.2000 & 5.0800 & 1.1700 & $\mathrm{P}=0.4250$ \\
\hline & 4.5300 & 1.4200 & 4.5300 & 1.1800 & $\mathrm{P}=0.9800$
\end{tabular}

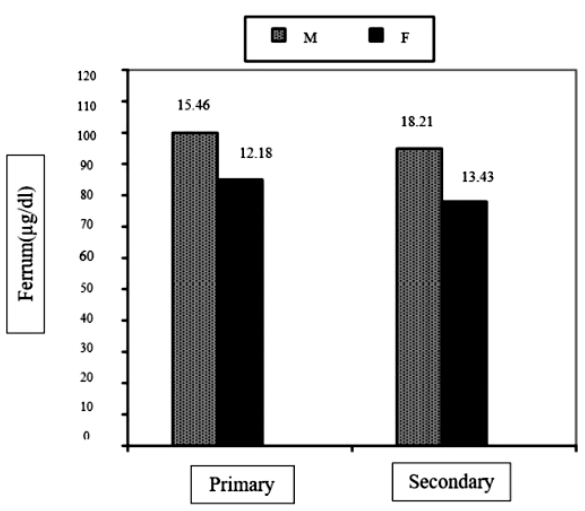

Figure 1. Comparison of primary and secondary serum iron levels by sex.

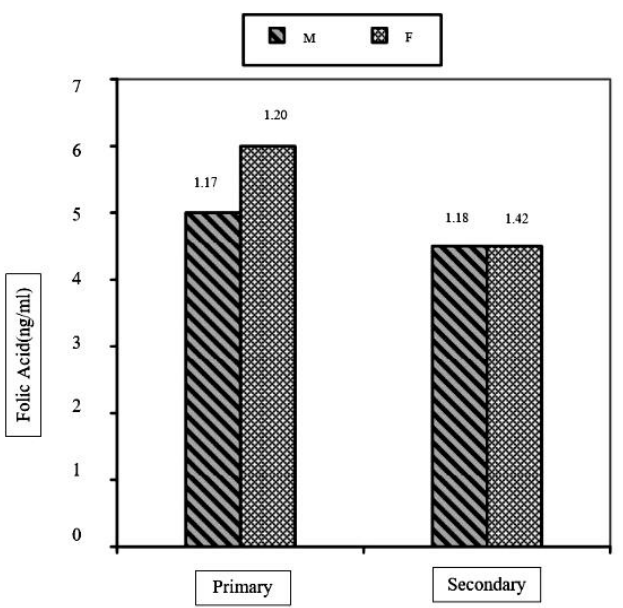

Figure 2. Comparison of primary and secondary levels of folic acid by sex.

Examining the amount of iron and primary folic acid (at the time of prosthesis delivery) in our study population shows that these values were below normal or, finally, in the lower limit of normal. The normal amount of iron is 50-1150 ng/day, and the normal amount of folic acid is 6-20 ng/ml. Since these people had undergone a period of 3-4 months of edentulousness before receiving the prosthesis, it seems that the negative effects of this period of edentulousness on a diet consumed and, of course, on the calories and minerals received, the 
main and important reason is low. Serum levels of iron and folic acid are present in these people [19, 21]. A study by Nowjack also found results consistent with this hypothesis [5], which showed that the intake and intake of foods rich in $\beta$-carotene and folate were lower in dentures than in those it is normal. It also seems that the old age of the subjects is another effective factor in reducing the values of our first sample [22].

A study by Scheffers also confirms our findings [9] that protein absorption and iron levels were lower in toothless women (with complete dentures). Examination of the secondary levels of iron and folic acid in the subjects showed that the amount of both did not increase and decreased in the case of folic acid. The reason for this decrease should also be sought in the inadequate intake of iron and folic acid from a poor diet [25, 27].

The body's iron stores are not much different from the original amount because they are larger and can supply longer. In addition, iron is in a greater diet than folic acid. It is almost possible to get it in this incomplete diet. A study by Shinkai et al. found that even with good quality toothpaste, levels of folic acid and other substances remained low [8]. Another study by Ettinger found that the use of alternative prostheses only affected performance and chewing and did not significantly alter dietary absorption [7].

Examining the results related to the changes of secondary to primary levels by sex in folic acid did not show any significant difference, while these changes were present in the amount of iron so that women were more iron deficient than men during the study period $[28,29]$. These results weakly support the hypothesis that men's diets are more complete than women because of better chewing power or faster adaptation to the replacement tooth because folic acid levels do not decrease unless the men's diet has been more iron. However, it seems that despite the high age of menopause in Iranian women (over 50 years) and considering that the average age of women in our study was higher (42-55 years) with the hypothesis of iron loss. More common in women, such as menstruation or increased iron intake due to pregnancy and other conditions.

\section{Conclusions}

According to this study's findings, we concluded that healthy teeth have an effective role in creating an effective and appropriate diet and providing the body with the necessary materials to replace them with artificial teeth could not improve the diet. Therefore, in addition to providing a suitable alternative prosthesis for these patients, dietary supplements should be prescribed to prevent the body's lack of nutrients.

\section{Funding}

This research received no external funding.

\section{Acknowledgments}

Author(s) thank the supports of the Amirkabir University of Technology and Tehran University of Medical Sciences.

\section{Conflicts of Interest}

The authors declare no conflict of interest. 


\section{References}

1. Maban, L.; Stamp, S. Krause's food nutrition diet therapy. 9th ed. Philadelphia: W.B. Saunders Co, 1996; pp. 717.

2. Harrison, A.; Tinsleg, R. Harrison's principles of medicine. 15th ed. V2. Philadelphia: W.B. Saunders Co; 2001; pp. 647, 660.

3. Bennett, J.; Goldman, L. Cecil textbook of medicine. 21th ed. V2. Philadelphia: W.B. Saunders Co; 2000; pp. 855 .

4. Beutler, E.; Coller, B.; Lichtman, M.; Kipps, T. Williams hematology. 6th ed. New York: Mc Graw-Hill, 2001; pp. 425.

5. Nowjack-Raymer, R.E.; Sheiham, A. Association of Edentulism and Diet and Nutrition in US Adults. Journal of Dental Research 2003, 82, 123-126, https://doi.org/10.1177/154405910308200209.

6. Marshall, T.A.; Warren, J.J.; Hand, J.S.; Xie, X.-J.; Stumbo, P.J. Oral health, nutrient intake and dietary quality in the very old. The Journal of the American Dental Association 2002, 133, 1369-1379, https://doi.org/10.14219/jada.archive.2002.0052.

7. Ettinger, R.L. Changing dietary patterns with changing dentition: how do people cope? Special care in dentistry : official publication of the American Association of Hospital Dentists, the Academy of Dentistry for the Handicapped, and the American Society for Geriatric Dentistry 1998, 18, 33-39, https://doi.org/10.1111/j.1754-4505.1998.tb01356.x.

8. Shinkai, R.S.A.; Hatch, J.P.; Rugh, J.D.; Sakai, S.; Mobley, C.C.; Saunders, M.J. Dietary intake in edentulous subjects with good and poor quality complete dentures. Journal of Prosthetic Dentistry 2002, 87, 490-498, https://doi.org/10.1067/mpr.2002.124093.

9. Scheffers, M.; ter Wee, J.; van Staveren, W.A.; Stafleu, A. Dentures and food selection. A survey in elderly women. Nederlands tijdschrift voor tandheelkunde 1995, 102, 453-455.

10. Brodeur, J.-M.; Laurin, D.; Vallee, R.; Lachapelle, D. Nutrient intake and gastrointestinal disorders related to masticatory performance in the edentulous elderly. Journal of Prosthetic Dentistry 1993, 70, 468-473, https://doi.org/10.1016/0022-3913(93)90087-5.

11. Chen, C.; Pan, K.; Wu, B.; Li, X.; Chen, Z.; Xu, Q.; Li, X.; Lv, Q. Safety of hydroxychloroquine in COVID19 and other diseases: a systematic review and meta-analysis of 53 randomized trials. European Journal of Clinical Pharmacology 2020, https://doi.org/10.1007/s00228-020-02962-5.

12. Ethinylestradiol/cyproterone. Reactions Weekly 2019, 1754, 153-153, https://doi.org/10.1007/s40278-01962386-9.

13. Everolimus/voriconazole. Reactions Weekly 2019, 1754, 156-156, https://doi.org/10.1007/s40278-01962389-9.

14. Hydroxychloroquine. Reactions Weekly 2019, 1754, 176-176, https://doi.org/10.1007/s40278-019-62409-2.

15. Wöstmann, B.; Simon, T.; Neuhäuser-Berthold, M.; Rehmann, P. Pilot Study on the Influence of Nutritional Counselling and Implant Therapy on the Nutritional Status in Dentally Compromised Patients. PLOS ONE 2016, 11, https://doi.org/10.1371/journal.pone.0147193.

16. Leigh-Ann, M.C.; Sinead, W.; McGowan, L.: McGuinness, B.; Cardwell. C.; Clarke, M.; Woodside, J.V.; McKenna, G. Development and Feasibility of A Tailored Habit-based Dietary Intervention Coupled With Natural Tooth Replacement On The Nutritional Status Of Older Patients. 24 July 2020, PREPRINT (Version 3) available at Research Square https://doi.org/10.21203/rs.3.rs-26975/v3.

17. Schimmel, M.; Genton, L.; McKenna, G. Masticatory Function and Nutritional Status: Considerations for an Ageing Population. In: Oral Rehabilitation for Compromised and Elderly Patients. Mersel, A. Ed. Springer International Publishing: Cham, 2019; https://doi.org/10.1007/978-3-319-76129-9_6.

18. McCrum, L.-A.; Watson, S.; McGowan, L.; McGuinness, B.; Cardwell, C.; Clarke, M.; Woodside, J.V.; McKenna, G. Development and feasibility of a tailored habit-based dietary intervention coupled with natural tooth replacement on the nutritional status of older patients. Pilot and Feasibility Studies 2020, 6, https://doi.org/10.1186/s40814-020-00654-6.

19. Afshin, A.; Sur, P.J.; Fay, K.A.; Cornaby, L.; Ferrara, G.; Salama, J.S.; Mullany, E.C.; Abate, K.H.; Abbafati, C.; Abebe, Z.; Afarideh, M.; Aggarwal, A.; Agrawal, S.; Akinyemiju, T.; Alahdab, F.; Bacha, U.; Bachman, V.F.; Badali, H.; Badawi, A.; Bensenor, I.M.; Bernabe, E.; Biadgilign, S.K.K.; Biryukov, S.H.; Cahill, L.E.; Carrero, J.J.; Cercy, K.M.; Dandona, L.; Dandona, R.; Dang, A.K.; Degefa, M.G.; El Sayed Zaki, M.; Esteghamati, A.; Esteghamati, S.; Fanzo, J.; Farinha, C.S.e.S.; Farvid, M.S.; Farzadfar, F.; Feigin, V.L.; Fernandes, J.C.; Flor, L.S.; Foigt, N.A.; Forouzanfar, M.H.; Ganji, M.; Geleijnse, J.M.; Gillum, R.F.; Goulart, A.C.; Grosso, G.; Guessous, I.; Hamidi, S.; Hankey, G.J.; Harikrishnan, S.; Hassen, H.Y.; Hay, S.I.; Hoang, C.L.; Horino, M.; Islami, F.; Jackson, M.D.; James, S.L.; Johansson, L.; Jonas, J.B.; Kasaeian, A.; Khader, Y.S.; Khalil, I.A.; Khang, Y.-H.; Kimokoti, R.W.; Kokubo, Y.; Kumar, G.A.; Lallukka, T.; Lopez, A.D.; Lorkowski, S.; Lotufo, P.A.; Lozano, R.; Malekzadeh, R.; März, W.; Meier, T.; Melaku, Y.A.; Mendoza, W.; Mensink, G.B.M.; Micha, R.; Miller, T.R.; Mirarefin, M.; Mohan, V.; Mokdad, A.H.; Mozaffarian, D.; Nagel, G.; Naghavi, M.; Nguyen, C.T.; Nixon, M.R.; Ong, K.L.; Pereira, D.M.; Poustchi, H.; Qorbani, M.; Rai, R.K.; Razo-García, C.; Rehm, C.D.; Rivera, J.A.; Rodríguez-Ramírez, S.; Roshandel, G.; Roth, G.A.; Sanabria, J.; Sánchez-Pimienta, T.G.; Sartorius, B.; Schmidhuber, J.; Schutte, A.E.; 
Sepanlou, S.G.; Shin, M.-J.; Sorensen, R.J.D.; Springmann, M.; Szponar, L.; Thorne-Lyman, A.L.; Thrift, A.G.; Touvier, M.; Tran, B.X.; Tyrovolas, S.; Ukwaja, K.N.; Ullah, I.; Uthman, O.A.; Vaezghasemi, M.; Vasankari, T.J.; Vollset, S.E.; Vos, T.; Vu, G.T.; Vu, L.G.; Weiderpass, E.; Werdecker, A.; Wijeratne, T.; Willett, W.C.; Wu, J.H.; Xu, G.; Yonemoto, N.; Yu, C.; Murray, C.J.L. Health effects of dietary risks in 195 countries, 1990-2017: A systematic analysis for the Global Burden of Disease Study 2017. The Lancet 2019, 393, 1958-1972, https://doi.org/10.1016/S0140-6736(19)30041-8.

20. Agostini, B.A.; Cericato, G.O.; Silveira, E.R.d.; Nascimento, G.G.; Costa, F.d.S.; Thomson, W.M.; Demarco, F.F. How Common is Dry Mouth? Systematic Review and Meta-Regression Analysis of Prevalence Estimates. J Brazilian Dental Journal 2018, 29, 606-618, https://doi.org/10.1590/01036440201802302.

21. Ali, Z.; Baker, S.R.; Shahrbaf, S.; Martin, N.; Vettore, M.V. Oral health-related quality of life after prosthodontic treatment for patients with partial edentulism: A systematic review and meta-analysis. Journal of Prosthetic Dentistry 2019, 121, 59-68.e53, https://doi.org/10.1016/j.prosdent.2018.03.003.

22. Bonaccio, M.; Di Castelnuovo, A.; Costanzo, S.; Gialluisi, A.; Persichillo, M.; Cerletti, C.; Donati, M.B.; de Gaetano, G.; Iacoviello, L. Mediterranean diet and mortality in the elderly: a prospective cohort study and a meta-analysis. British Journal of Nutrition $2018, \quad$ 120, https://doi.org/10.1017/S0007114518002179.

23. Kaushik, K.; Dhawan, P.; Tandan, P.; Jain, M. Oral health-related quality of life among patients after complete denture rehabilitation: A 12-month follow-up study. 2018, 8, 169-173, https://doi.org/10.4103/ijabmr.IJABMR_171_18.

24. Nabeshima, G.; Fueki, K.; Inamochi, Y.; Wakabayashi, N. Effect of dietary counselling with prosthetic restoration on fruit and vegetable intake in partially dentate patients: A prospective study. J Oral Rehabil 2018, 45, 618-626.

25. Reynolds, A.; Mann, J.; Cummings, J.; Winter, N.; Mete, E.; Te Morenga, L. Carbohydrate quality and human health: a series of systematic reviews and meta-analyses. The Lancet 2019, 393, 434-445, https://doi.org/10.1016/S0140-6736(18)31809-9.

26. Toniazzo, M.P.; Amorim, P.d.S.A.; Muniz, F.W.M.G.; Weidlich, P. Relationship of nutritional status and oral health in elderly: Systematic review with meta-analysis. Clinical Nutrition 2018, 37, 824-830, https://doi.org/10.1016/j.clnu.2017.03.014.

27. Watson, S.; McGowan, L.; McCrum, L.-A.; Cardwell, C.; McGuinness, B.; Moore, C.; Woodside, J.; McKenna, G. The impact of dental status on perceived ability to eat certain foods and nutrient intakes in older adults: Cross-sectional analysis of the UK National Diet and Nutrition Survey 2008-2014. International Journal of Behavioral Nutrition and Physical Activity 2019, 16, https://doi.org/10.1186/s12966-019-0803-8.

28. Alkhouli, M.; Farooq, A.; Go, R.S.; Balla, S.; Berzingi, C. Cardiac prostheses-related hemolytic anemia. Clinical Cardiology 2019, 42, 692-700, https://doi.org/10.1002/clc.23191.

29. Širáková, A.; Toušek, P.; Bednář, F.; Línková, H.; Laboš, M.; Sulženko, J.; Havlíková, M.; Neuberg, M.; Kočka, V. Intravascular haemolysis after transcatheter aortic valve implantation with self-expandable prosthesis: incidence, severity, and impact on long-term mortality. European Heart Journal Supplements 2020, 22, F44-F50, https://doi.org/10.1093/eurheartj/suaa098. 